\title{
REFORMULASI METODE KONVERSI SUARA MENJADI KURSI DALAM SISTEM PEMILIHAN UMUM LEGISLATIF DI INDONESIA
}

(Reformulation of Vote Conversion into seat Method in Legislative Election System of Indonesia)

\author{
Dian Agung Wicaksono \\ Bagian Hukum Tata Negara Fakultas Hukum Universitas Gadjah Mada \\ J. Sosio Yustisia No. 1 Bulaksumur, Sleman D.I. Yogyakarta
}

Email: dianagung@ugm.ac.id

Naskah diterima: 30 Maret 2014; revisi: 14 April 2014; disetujui: 29 April 2014

\begin{abstract}
Abstrak
Salah satu bagian dari sistem pemilihan umum (pemilu) yang terlihat sangat sederhana dan bahkan hampir tidak diperhatikan secara khusus adalah metode konversi suara pemilih menjadi kursi anggota legislatif. Sejatinya pengaturan mengenai metode konversi suara menjadi kursi telah diatur dalam UU, setidaknya sejak tahun 2004. Muncul pertanyaan mendasar bagaimana implikasi perpaduan antara sistem presidensial dan sistem kepartaian multipartai di Indonesia? Bagaimana politik hukum metode konversi suara menjadi kursi dalam sistem pemilu legislatif? Bagaimana evaluasi dan alternatif solusi terhadap penerapan metode konversi terhadap upaya penyederhanaan sistem multipartai di Indonesia? Penelitian ini adalah penelitian hukum normatif untuk mendapatkan data sekunder. Tentu perdebatan yang dibangun dalam konteks hukum tata negara bukanlah mana yang benar dan mana yang salah, namun lebih pada konteks implikasi yang ditimbulkan dari pilihan kebijakan terhadap sistem ketatanegaraan Indonesia. Dalam konteks kompleksitas perpaduan sistem pemerintahan presidensial dan sistem kepartaian multipartai, sudah selayaknya apapun pilihan kebijakan yang dibangun dalam kerangka politik hukum sistem pemilu di Indonesia haruslah mendukung terciptanya efektivitas sistem presidensial.

Kata Kunci: Reformulasi, Metode Konversi Suara, Pemilu Legislatif
\end{abstract}

\section{Abstract}

The simple part of election system is vote conversion method. The method to convert the total amount of votes into the seats of legislator almost abandoned. Actually, the method should be regulated in 2004 Legislative Election Act. Arise a basic question, how the implication of combination between presidentialism and multiparty system in Indonesia? How the regulation on vote conversion method in legislative election system? And, how the evaluation and solution alternative toward the implementation of vote conversion method in order to simplify the multiparty system in Indonesia? This is a normative legal research that collect secondary data. In the context of constitution law debate whether what is right or what is wrong, but rather in the context of the implications from the legal policy. In the context of complexity of fusion presidentialism and multi-party system, that is proper that any legal policy is built within the framework to support presidentialism effectiveness.

Keywords: Reformulation, Votes Conversion Method, Legislative Election 


\section{A. Pendahuluan}

Dalam rezim pemilihan umum (pemilu) Indonesia dikenal beberapa jenis pemilu yang diselenggarakan untuk memilih: (a) anggota Dewan Perwakilan Rakyat; (b) anggota Dewan Perwakilan Daerah; (c) Presiden dan Wakil Presiden; dan (d) Dewan Perwakilan Rakyat Daerah. ${ }^{1}$ Secara dikotomis, rezim pemilu di atas dapat digolongkan atas dasar apa yang dipilih dalam pemilu, sehingga dapat dibedakan dalam 2 jenis, yaitu pemilu presiden dan pemilu legislatif. Hal yang penting dalam pelaksanaan pesta demokrasi rakyat Indonesia tersebut selain aspek partisipasi pemilih juga adalah sistem pemilu yang menjadi sarana dalam mengartikulasikan daulat rakyat melalui media pemilu. Perekayasaan sistem pemilu menjadi hal yang penting untuk dilakukan membenahi tatanan politik demokrasi, manajemen proses penyelenggaraan pemilu, integritas proses dan hasil pemilu, serta penyelesaian sengketa pemilu. $^{2}$

Spesifik dalam konteks pemilu legislatif, salah satu bagian dari sistem pemilu yang terlihat sangat sederhana dan bahkan hampir tidak diperhatikan secara khusus adalah metode konversi suara pemilih menjadi kursi anggota legislatif. Pandangan awam menempatkan yang lebih penting adalah bagaimana meraup suara sebanyak-banyaknya sehingga dapat duduk di lembaga legislatif. Terlebih putusan Mahkamah
Konstitusi semakin meneguhkan pandangan tersebut bahwa pemilu legislatif ditentukan oleh suara terbanyak dan bukan lagi nomor urut calon anggota legislatif. ${ }^{3}$

Sejatinya pengaturan mengenai metode konversi suara menjadi kursi telah diatur dalam Undang-Undang Nomor 8 Tahun 2012 tentang Pemilihan Umum Dewan Perwakilan Rakyat, Dewan Perwakilan Daerah dan Dewan Perwakilan Rakyat Daerah (UU Pemilu Legislatif). Hal tersebut dapat diketahui pada Pasal 212213 UU Pemilu Legislatif yang secara tegas memilih sebuah formulasi untuk mengkonversi jumlah suara menjadi kursi. Hal pertama yang harus dilakukan adalah menetapkan angka BPP. ${ }^{4}$ Setelah itu ditetapkan perolehan jumlah kursi tiap Partai Politik Peserta Pemilu di suatu daerah pemilihan, dengan ketentuan: (a) apabila jumlah suara sah suatu Partai Politik Peserta Pemilu sama dengan atau lebih besar dari BPP, maka dalam penghitungan tahap pertama diperoleh sejumlah kursi dengan kemungkinan terdapat sisa suara yang akan dihitung dalam penghitungan tahap kedua; (b) apabila jumlah suara sah suatu Partai Politik Peserta Pemilu lebih kecil daripada BPP, maka dalam penghitungan tahap pertama tidak diperoleh kursi, dan jumlah suara sah tersebut dikategorikan sebagai sisa suara yang akan dihitung dalam penghitungan tahap kedua dalam hal masih terdapat sisa kursi di daerah pemilihan yang bersangkutan; dan

Pasal 22E ayat (2) Undang-Undang Dasar Negara Republik Indonesia Tahun 1945.

2 Ramlan Surbakti, Didik Supriyanto, dan Topo Santoso, Perekayasaan Sistem Pemilu untuk Pembangunan Tata Politik Demokratis (Jakarta: Partnership for Governance Reform Indonesia, 2008), hlm. 1.

3 Lihat dalam Putusan Mahkamah Konstitusi Nomor 22-24/PUU-VI/2008 perihal Pengujian Undang-Undang Nomor 10 Tahun 2008 tentang Pemilihan Umum Anggota Dewan Perwakilan Rakyat, Dewan Perwakilan Daerah, dan Dewan Perwakilan Rakyat Daerah terhadap Undang-Undang Dasar Negara Republik Indonesia Tahun 1945. Pasal 211 ayat (2) Undang-Undang Nomor 8 Tahun 2012 tentang Pemilihan Umum Dewan Perwakilan Rakyat, Dewan Perwakilan Daerah dan Dewan Perwakilan Rakyat Daerah (Lembaran Negara Republik Indonesia Tahun 2012 Nomor 117, Tambahan Lembaran Negara Republik Indonesia Nomor 5316). 
(c) penghitungan perolehan kursi tahap kedua dilakukan apabila masih terdapat sisa kursi yang belum terbagi dalam penghitungan tahap pertama, dengan cara membagikan jumlah sisa kursi yang belum terbagi kepada Partai Politik Peserta Pemilu satu demi satu berturut-turut sampai habis, dimulai dari Partai Politik Peserta Pemilu yang mempunyai sisa suara terbanyak. ${ }^{5}$ Dalam hal terdapat sisa suara Partai Politik Peserta Pemilu di suatu daerah pemilihan sama jumlahnya, maka kursi diberikan kepada Partai Politik Peserta Pemilu yang sisa suaranya memiliki persebaran yang lebih banyak. ${ }^{6}$

Dengan mencermati rumusan norma di atas, muncul pertanyaan mendasar mengapa formula tersebut dipilih dalam politik hukum sistem pemilu di Indonesia sebagai metode dalam mengkonversi suara menjadi kursi. Padahal dari sisi justifikasi teoritik dikenal lebih dari 1 (satu) metode untuk mengkonversi jumlah suara menjadi kursi. Indonesia sebagai negara yang menerapkan sistem pemilu list proportional representation (List $P R$ ) dengan open list system mengadopsi largest remainder untuk melakukan penghitungan suara. ${ }^{2}$ Largest remainder diperoleh dengan menentukan kuota suara dan besarnya kursi yang diperoleh masing-masing partai berdasarkan jumlah suara yang diperoleh, sedangkan sisa suara yang belum terbagi akan diberikan kepada partai yang mempunyai jumlah sisa suara terbesar, yang mana dalam largest remainder dikenal 2 metode penghitungan, yaitu: (a) Kuota Hare (Hare Quota/HQ), yang dihitung berdasarkan jumlah total suara yang sah (vote/v) dibagi dengan jumlah kursi yang disediakan dalam suatu distrik (seat/s); dan (b) Kuota Droop (Droop Quota/DQ), yang dihitung dari jumlah total suara (vote/v) dibagi dengan jumlah kursi yang disediakan dalam suatu distrik (seat/s) ditambah $1 .{ }^{8}$

Tentu perdebatan yang dibangun dalam konteks hukum tata negara bukanlah mana yang benar dan mana yang salah, namun lebih pada konteks implikasi yang ditimbulkan dari pilihan kebijakan terhadap sistem ketatanegaraan Indonesia. Dalam konteks kompleksitas perpaduan sistem pemerintahan presidensial dan sistem kepartaian multipartai, sudah selayaknya apapun pilihan kebijakan yang dibangun dalam kerangka politik hukum sistem pemilu di Indonesia haruslah mendukung terciptanya efektivitas sistem presidensial. Karena bagaimanapun harus dipahami bahwa sistem presidensial hanya menjanjikan stabilitas namun tidak memberikan garansi efektivitas. Dengan dalil bahwa efektivitas pemerintahan seorang presiden tergantung pada dukungan dalam pemilihan (electoral support) yang berubah menjadi sokongan dalam

5 Pasal 212 Undang-Undang Nomor 8 Tahun 2012 tentang Pemilihan Umum Dewan Perwakilan Rakyat, Dewan Perwakilan Daerah dan Dewan Perwakilan Rakyat Daerah (Lembaran Negara Republik Indonesia Tahun 2012 Nomor 117, Tambahan Lembaran Negara Republik Indonesia Nomor 5316).

6 Pasal 213 Undang-Undang Nomor 8 Tahun 2012 tentang Pemilihan Umum Dewan Perwakilan Rakyat, Dewan Perwakilan Daerah dan Dewan Perwakilan Rakyat Daerah (Lembaran Negara Republik Indonesia Tahun 2012 Nomor 117, Tambahan Lembaran Negara Republik Indonesia Nomor 5316).

AAGN Ari Dwipayana, Mengenal Beberapa Sistem Pemilu (Yogyakarta: Fakultas Ilmu Sosial dan Ilmu Politik Universitas Gadjah Mada, Yogyakarta).

8 Sigit Pamungkas, Perihal Pemilu (Yogyakarta: Laboratorium Jurusan Ilmu Pemerintahan dan Jurusan Ilmu Pemerintahan Universitas Gadjah Mada, 2009), hlm. 32. 
pemerintahan (governing support), ${ }^{9}$ maka menjadi penting untuk memilih sistem pemilu yang mendukung konstelasi governing support dengan menyederhanakan sistem kepartaian multipartai menjadi lebih sederhana.

\section{B. Permasalahan}

Permasalahan yang menjadi fokus pembahasan dalam penelitian ini adalah, Pertama, bagaimana implikasi perpaduan antara sistem presidensial dan sistem kepartaian multipartai di Indonesia? Kedua, bagaimana politik hukum metode konversi suara menjadi kursi dalam sistem pemilu legislatif? Ketiga, bagaimana evaluasi dan alternatif solusi terhadap penerapan metode konversi terhadap upaya penyederhanaan sistem multipartai di Indonesia? Hal tersebut menjadi penting mengingat penyederhanaan sistem multipartai merupakan salah satu upaya untuk mendorong terciptanya efektivitas sistem presidensial di Indonesia. Melalui penelitian ini diharapkan terbangun pola pikir pengambil kebijakan pemilu bahwa diperlukan suatu mekanisme untuk menyederhanakan sistem multipartai melalui cara-cara yang elegan. Selain itu, tentunya tujuan dari penyederhanaan partai ini akan mendorong kinerja pemerintahan yang efektif. Bagaimanapun sistem presidensial di negara ini akan tumbuh dan berkembang dengan semangat purifikasi dalam konstitusi dengan didukung oleh atmosfer dan habitat multipartai yang tidak mereduksi kekuasaan presiden.

\section{Metode Penelitian}

\section{Sifat Penelitian}

Penelitian ini adalah penelitian hukum normatif yang dilakukan menggunakan penelitian kepustakaan. Penelitian kepustakaan dilakukan untuk mendapatkan data sekunder dengan bahan atau materi berupa bukubuku, artikel-artikel, hasil-hasil penelitian, dan peraturan perundang-undangan, serta pendapat ahli yang berkaitan dengan metode konversi suara menjadi kursi dalam sistem pemilu legislatif Indonesia.

\section{Bahan Penelitian}

Penelitian kepustakaan menggunakan alat studi dokumen. Bahan penelitian ini berupa buku-buku, artikel-artikel, hasil-hasil penelitian, dan peraturan perundang-undangan, serta pendapat ahli yang berkaitan tentang berkaitan dengan metode konversi suara menjadi kursi dalam sistem pemilu legislatif Indonesia.

\section{Cara Pengambilan Data}

Cara pengambilan data dalam penelitian ini adalah dengan melakukan studi pustaka terhadap buku-buku, artikel-artikel, hasilhasil penelitian, dan peraturan perundangundangan, serta pendapat ahli yang berkaitan dengan metode konversi suara menjadi kursi dalam sistem pemilu legislatif Indonesia. Lebih dahulu dilakukan analisis politik hukum sistem pemilu legislatif di Indonesia dan dikaitkan dengan sistem pemerintahan presidensial di Indonesia dengan mencari referensi yang ada pada buku, artikel, dan hasil penelitian yang sudah ada sebelumnya. Kemudian akan 
dianalisis metode konversi suara menjadi kursi dalam sistem pemilu legislatif Indonesia. Selanjutnya dianalisis lebih lanjut implikasi pemilihan metode konversi tersebut terhadap upaya penyederhanaan sistem multipartai di Indonesia, sehingga dapat berkontribusi positif pada efektivitas kinerja pemerintahan presidensial di Indonesia. Selain itu, juga ditampilkan sampel penggunaan metode kuota Droop dengan mengambil data hasil Pemilu DPR RI Tahun 2009 di wilayah D.I. Yogyakarta, dengan penggunaan contoh data tersebut dapat dijadikan patokan seberapa efektif penggunaan metode kuota Droop ini dibandingkan dengan metode kuota Hare dalam rangka mereduksi jumlah partai politik.

Dalam penelitian hukum normatif, data yang terkait dengan penelitian dianalisis secara deskriptif-kualitatif, yaitu dengan melakukan analisis yang pada dasarnya dikembalikan pada tiga aspek, yaitu mengklasifikasi, membandingkan, dan menghubungkan. Dengan perkataan lain, seorang peneliti yang mempergunakan metode kualitatif, tidaklah sematamata bertujuan mengungkapkan kebenaran belaka, akan tetapi untuk memahami kebenaran tersebut. Terhadap data-data yang telah terkumpul dari penelitian kepustakaan selanjutnya akan dianalisis secara kualitatif untuk menjawab permasalahan penelitian yang diajukan.

\section{Pembahasan}

1. Sistem Pemerintahan Presidensial, Sistem Kepartaian Multipartai, dan Ketidakefektifannya

Sistem pemerintahan di dunia secara sederhana dapat diklasifikasikan berdasarkan substansi jabatan kepala pemerintahan. Banyak ahli hukum maupun politik yang memberikan definisi dengan karakteristik yang hampir sama. Spesifik dalam konteks sistem pemerintahan presidensial, Giovanni Sartori menjelaskan karakter sistem presidensial yang diwujudkan dengan sistem politik jika dan hanya jika presidennya: (1) dipilih langsung oleh rakyat (popular election); (2) tidak bisa dicabut atau dihapuskan oleh pemungutan suara di parlemen, selama dalam masa jabatannya (fixed term); dan (3) memimpin pemerintah yang dipilih dan diangkatnya sendiri. ${ }^{10}$ Indonesia merupakan salah satu negara yang menerapkan sistem pemerintahan presidensial. Berdasarkan kriteria Sartori di atas, harus ada sebuah pemilu yang digunakan oleh rakyat untuk memilih presidennya. Maurice Duverger menjelaskan pengaruh sistem-sistem pemerintahan secara menyeluruh, yang mana sistem pemilu yang dipilih akan berpengaruh terhadap pemerintahan. ${ }^{11}$

Indonesia sampai saat ini masih menganut sistem multipartai, yakni terdapat lebih dari satu partai politik yang bersaing dalam pemilu. Permasalahan yang terjadi adalah bagaimana menyelaraskan sistem pemerintahan presidensial dan sistem pemilihan multipartai. Sistem presidensial menghendaki adanya

10 Giovanni Sartori, Comparative Constitutional Engineering: An Inquiry into Structure, Incentives, and Outcomes (London: Macmillan Press Ltd., 1997), hlm. 84.

11 Ichlasul Amal, Teori-Teori Mutakhir Partai Politik (Yogyakarta: Gadjah Mada University Press, 1996$),$ hlm. 66. 
kekuasaan presiden yang kuat. Realita yang terjadi di Indonesia, menunjukkan sistem multipartai berpengaruh pada lemahnya posisi presiden di hadapan parlemen. Jumlah partai politik yang sangat banyak menyebabkan polarisasi kepentingan di parlemen semakin kuat. Efektivitas sistem pemerintahan presidensial di Indonesia akan sulit tercapai karena presiden harus mempunyai dukungan parpol yang kuat di parlemen.

Dalam hal menilai efektivitas kinerja pemerintahan, dalam hal ini Presiden, tentu tidak dapat dilepaskan penilaian tersebut terhadap sistem presidensial yang dijadikan mekanisme kinerja pemerintahan. Sistem presidensial di Indonesia yang berjalan di tengah kawalan sistem multipartai di lembaga perwakilan rakyat menyebabkan suatu kondisi apriori yang berdampak pada pelaksanaan kekuasaan presiden dalam sistem presidensial. Kondisi apriori a quo muncul dikarenakan kombinasi sistem multipartai dan sistem pemerintahan presidensial yang membuat konstelasi partai politik yang duduk di lembaga perwakilan rakyat menjadi sangat sulit untuk dilakukan legal engineering. Dinamika hubungan antara presiden dengan lembaga perwakilan rakyat secara tidak langsung akan mereduksi kekuasaan presiden dalam mengeksekusi program-program kerjanya (rule-application function $)^{12}$. Presiden tidak dapat dengan leluasa melaksanakan program-program kerjanya karena tersandera dengan kepentingan politik yang diusung oleh konstelasi partai politik di lembaga perwakilan rakyat.

Justru menjadi suatu pertanyaan ketika Presiden dengan desain konstitusi yang kuat, karena salah satu komitmen perubahan konstitusi adalah purifikasi sistem presidensial, ${ }^{13}$ tetapi justru dalam implementasinya melahirkan kondisi presiden yang mengalami keterbatasan dalam bergerak oleh karena konstelasi politik. Contoh yang tidak terbantahkan akan semakin tereduksinya kekuasaan presiden adalah sandera politik atas kebijakan Presiden SBY untuk menaikkan harga BBM Bersubsidi yang ditolak oleh DPR. ${ }^{14}$ Secara nyata hal tersebut menunjukkan bahwa DPR memang lebih dominan daripada kekuasaan presiden yang menjabat sebagai kepala negara sekaligus sebagai kepala pemerintahan.

Bukti lain ketidakefektifan pemerintahan adalah rendahnya produktivitas legislasi. Bila dilihat dari Undang-Undang (UU) yang telah disahkan sangatlah jauh dari yang direncanakan dalam Program Legislasi Nasional (Prolegnas). Dalam Prolegnas Tahun 2010-2014 ditetapkan sebanyak 247 RUU dan 5 RUU Kumulatif Terbuka. ${ }^{15}$ Mengambil sampel kinerja legislasi pada tahun 2013 dan 2014, fungsi legislasi DPR masih belum memuaskan. Tercatat, sebanyak 66 RUU disahkan masuk dalam Prolegnas 2104, yang mana 34 RUU dari 66 RUU Prolegnas 2014 merupakan sisa RUU Prolegnas 2013 masih dalam tahap Pembahasan Tingkat I, 6 RUU dalam tahap harmonisasi di Badan Legislasi

Miriam Budiardjo, Dasar-Dasar Ilmu Politik (Jakarta: Gramedia Pustaka Utama, 2003), hlm. 158.

13 Kelompok Kerja Forum Rektor Indonesia, Penyempurnaan Amandemen Undang-Undang Dasar 1945 (Hasil Kerja Kelompok Kerja Forum Rektor Indonesia 2006-2007) (Yogyakarta: Gadjah Mada University Press, 2007), hlm. 14. Ahyar, "Drama Sandera Kebijakan Presiden SBY Menaikkan Harga BBM Bersubsidi untuk Rakyat Miskin", http:// www.ronamasa.com/2013/06/drama-sandera-kebijakan-presiden-sby.html (diakses 30 Maret 2014).

15 Dewan Perwakilan Rakyat RI, Program Legislasi Nasional Tahun 2010-2014 (Jakarta: Badan Legislasi DPR RI, 2010), hlm. 13. 
DPR, 13 RUU dalam tahap akhir penyusunan oleh DPR, 7 RUU dalam tahap akhir penyusunan oleh Pemerintah, 4 RUU baru disiapkan DPR, 1 RUU baru disiapkan oleh Pemerintah, dan 1 RUU disiapkan oleh DPD. ${ }^{16}$ Selain itu, dari UU yang sudah disahkan pun juga tidak bebas dari pengujian di Mahkamah Konstitusi. ${ }^{17}$

Secara analitis, dapat diketemukan suatu ketimpangan antara staatsgrundgesetz dan formeel gesetz terkait relasi antara eksekutif dan legislatif. Dalam ranah staatsgrundgesetz ditemukan suatu desain konstitusional yang kuat dibuktikan dengan komitmen perubahan yang menghendaki purifikasi sistem presidensial. Namun, di sisi lain dalam ranah formeel gesetz dapat ditemukan setidak-tidaknya ada 3 UU yang sangat mempengaruhi implementasi substansi sistem presidensial dalam kehidupan ketatanegaraan Indonesia, yaitu UU Pemilihan Umum (UU Pemilu), UU Partai Politik, dan UU MPR, DPR, DPD, dan DPRD (UU MD3). Ketiga UU tersebut merupakan framework desain dan panduan pelaksanaan pemilu, serta pengaturan mengenai kedudukan kelembagaan hasil pemilu, yang sedikit banyak mempengaruhi dinamika implementasi sistem presidensial di Indonesia.

Dengan demikian dapat disimpulkan bahwa permasalahan klasik yang dihadapi oleh pemerintahan presidensial Indonesia yang dipadukan dengan balutan sistem multipartai adalah proses kooptasi kekuasaan yang dilakukan oleh partai politik melalui kaderkadernya di lembaga perwakilan rakyat. Untuk itu, salah satu cara untuk meminimalisir semakin melemahnya kekuasaan presiden, serta untuk meningkatkan keefektifan kinerja pemerintahan adalah dengan menyederhanakan sistem multipartai, sehingga dengan semakin sedikitnya partai politik yang duduk di lembaga perwakilan rakyat, maka proses pelaksanaan pemerintahan akan berjalan lebih efektif. Pada dasarnya penyederhanaan partai politik memang hal yang diamanatkan oleh konstitusi, buktinya adalah dengan munculnya undangundang yang mengatur tentang partai politik dan sistem pemilu, karena pada hakikatnya, undang-undang memang dimaksudkan untuk pembatasan partai politik. ${ }^{18}$

Mengutip pendapat Denny Indrayana, ${ }^{19}$ setidaknya ada 3 cara untuk membuat sistem presidensial ini kembali dalam rel kerja yang efektif kembali, yaitu: (1) moralitas presiden; (2) desain konstitusional yang kuat; dan (3) melakukan penyederhanaan partai politik. Untuk poin pertama tentunya sangatlah bergantung pada seperti apa presiden yang terpilih dan tentunya sulit untuk diupayakan. Untuk poin kedua pada dasarnya hal tersebut telah ada di Indonesia, hanya saja diperlemah pada tataran UU. Dengan demikian, hal yang dapat dilakukan sebagai bentuk legal

16 Hukum Online, "DPR Tetapkan 66 RUU Prolegnas 2014", http://www.hukumonline.com/berita/baca/ lt52b063fdb092e/dpr-tetapkan-66-ruu-prolegnas-2014 (diakses 29 Maret 2014).

17 Mahkamah Konstitusi RI, "Rekapitulasi Perkara Pengujian Undang-Undang", http://www.mahkamahkonstitusi. go.id/index.php?page=web.RekapPUU (diakses 30 Maret 2014).

18 Putusan Mahkamah Konstitusi Nomor 3/PUU-VII/2009 perihal Pengujian Undang-Undang Nomor 10 Tahun 2008 tentang Pemilihan Umum Anggota Dewan Perwakilan Rakyat, Dewan Perwakilan Daerah, dan Dewan Perwakilan Rakyat Daerah terhadap Undang-Undang Dasar Negara Republik Indonesia Tahun 1945, hlm. 130.

19 Denny Indrayana,"Sistem Pemilu Presiden/Wakil Presiden 2009",(Bahan Kuliah Video Conference diselenggarakan oleh Fakultas Hukum Universitas Gadjah Mada dengan Mahkamah Konstitusi RI, Yogyakarta, 19 Februari 2009). 
engineering untuk selanjutnya dituangkan sebagai legal policy adalah poin ketiga tentang penyederhanaan partai politik.

Banyak anggapan yang muncul bahwa dengan adanya penyederhanaan partai politik ini hanya akan menguntungkan partai-partai besar, namun seharusnya perlu ditelaah lagi bahwa pada dasarnya idealita demokrasi itu menyangkut pluralitas ide untuk bisa dilembagakan melalui kanalisasi oleh partai politik untuk diperjuangkan di parlemen. ${ }^{20}$ Jadi, sebesar apapun partai politik, ketika memang partai politik tersebut tidak lagi dapat membawa perubahan dan tidak lagi sensitif terhadap perubahan, maka menjadi suatu keniscayaan partai besar ini akan ditinggalkan oleh konstituennya dan akan beralih kepada partai kecil yang notabene masih baru, namun dapat membawa kepentingan masyarakat untuk diperjuangkan di lembaga perwakilan rakyat.

\section{Sistem Pemilu di Indonesia dengan List Proportional Representation with Open List System}

Sistem representasi proporsional (proportional representation) atau lebih dikenal dengan perwakilan berimbang adalah metode konversi suara pemilih ke kursi di parlemen sesuai dengan proporsi perolehan suara pemilih. Dibanding dengan sistem distrik, sistem proporsional lebih banyak digunakan oleh negara-negara di dunia. Pertimbangan utama negara-negara yang mempergunakan sistem ini biasanya berangkat dari keberatan terhadap sistem distrik yang tingkat disproporsionalitasnya sangat tinggi.
Varian dari sistem proporsional representatif meliputi: (a) List Proportional Representation (List PR); (b) Mixed Member Proportional (MMP); dan (c) Single Transferable Vote (STV). ${ }^{21}$

Pembahasan ini hanya akan berfokus pada sistem List Proportional Representative (List PR) sebagai sistem yang digunakan di Indonesia. List Proportional Representative (List PR) pada dasarnya ada dua bentuk, yaitu sistem daftar tertutup (Closed List System) dan sistem daftar terbuka (Open List System). Dalam sistem daftar tertutup, para pemilih harus memilih partai politik peserta pemilu, dan tidak bisa memilih calon legislatif. Dalam sistem ini, para calon legislatif telah ditentukan dan diurutkan secara sepihakoleh partai politik yang mencalonkannya. Sementara pada sistem daftar terbuka (Open List System), para pemilih bukan hanya dapat memilih partai politik yang diminati, namun juga berkesempatan menentukan sendiri calon legislatif yang disukainya. Dengan demikian, pemilih di samping memilih tanda gambar partai juga memilih gambar kandidat legislatif.

Dalam konteks Indonesia, sistem yang digunakan adalah List PR with Open List System. Dalam sistem List $P R$, transfer suara ke kursi bisa dilakukan melalui dua cara, yaitu:(a) berdasarkan rata-rata tertinggi atau biasa disebut dengan pembagi (devisor); dan (b) suara sisa terbesar (largest remainder) atau disebut dengan kuota. ${ }^{22} \mathrm{Di}$ Indonesia mengadopsi cara largest remainder untuk melakukan penghitungan suara. Langkah-langkahnya adalah menentukan kuota suara dan besarnya kursi yang diperoleh masing-masing partai berdasarkan jumlah suara

Daniel Sparingga, "Penyederhanaan Partai, Agenda Reformasi", Suara Karya, 14 Juli 2007.

21 Ben Reilly dan Andrew Reynolds, Electoral Systems and Conflict in Divided Societies (Washington, DC: National Academy Press, 1999), hlm. 22.

22 Harun Husein, "Berhitung Kursi Secara Fair", Republika, 12 Juli 2011. 
yang diperoleh. Sementara sisa suara yang belum terbagi akan diberikan kepada parpol yang mempunyai jumlah sisa suara terbesar.

Dalam largest remainder dikenal 2 metode penghitungan, yaitu: $:^{23}$

a. Kuota Hare (Hare Quota/HQ)

$$
H Q=\frac{v}{s}
$$

Kuota Hare (Hare Quota/HQ) dihitung berdasarkan jumlah total suara yang sah (vote $/ v)$ dibagi dengan jumlah kursi yang disediakan dalam suatu distrik (seat/s).

b. Kuota Droop (Droop Quota/DQ)

$$
D Q=\frac{v}{s+1}
$$

Kuota Droop (Droop Quota/DQ) dihitung dari jumlah total suara (vote $/ v)$ dibagi dengan jumlah kursi yang disediakan dalam suatu distrik (seat/s) ditambah 1.

Selanjutnya perlu dibahas pula mengenai District Magnitude yang menjadi salah satu unsur dalam pemilu legislatif. Besaran Distrik (District Magnitude/DM) adalah berapa banyak kursi yang diperebutkan dalam suatu daerah pemilihan. Dalam pembagian DM dikenal 3 kategori, yaitu: (a) Kategori Distrik Kecil (2-5 kursi); (b) Kategori Distrik Sedang (6-10 kursi); (c) Kategori Distrik Besar (>10 kursi). ${ }^{14}$ Semakin besar DM maka tingkat persaingan partai politik semakin rendah untuk memperebutkan kursi yang ada di daerah pemilihan tersebut, begitu pula sebaliknya ketika DM diperkecil, maka secara kausal tingkat kompetisi partai politik akan semakin tinggi dalam memperebutkan kursi. Disinilah sebenarnya mekanisme kontrol akan kualitas dari partai politik dapat dilaksanakan.

\section{Evaluasi Metode Konversi Suara Menjadi Kursi dalam Sistem Pemilihan Umum Legislatif}

Berdasarkan pembahasan sebelumnya dapat disimpulkan bahwa sistem presidensial yang diamanatkan oleh UUD 1945 hasil amandemen, ternyata tidak satu framework dengan sistem kepartaian multipartai. Hal ini berakibat pada ketidakstabilan penyelenggaraan pemerintahan yang tercermin dari hubungan antara eksekutif dan legislatif. Kemudahan dalam mendirikan partai politik belum diimbangi dengan persyaratan secara kualitatif untuk dapat ikut serta dalam pemilu, sehingga atmosfer multipartai yang berkembang adalah suatu euforia berpolitik tanpa ada substansi demokrasi. Untuk itu diperlukan suatu rekayasa hukum dan pilihan kebijakan untuk menyederhanakan partai politik tanpa merusak iklim berdemokrasi.

Terkait dengan dalam upaya untuk melakukan legal engineering ${ }^{24}$ dan legal policy terhadap penyederhanaan sistem multipartai, setidak-tidaknya terdapat empat cara untuk melakukan penyederhanaan sistem multipartai tanpa melakukan pemaksaan pembubaran partai politik, antara lain: (a) Diberlakukannya political parties threshold, yang dimaksud di sini adalah syarat partai politik untuk menjadi peserta Pemilu yang diperketat; (b)

23 Sigit Pamungkas, Loc.cit.

24 Tom M.van Engers, "Legal Engineering: A Structural Approach to Improving Legal Quality" (Paper on Applications and Innovations in Intelligent Systems XIII, Proceedings of AI-2005). 
Diberlakukannya parliamentary threshold, yang dimaksud adalah ambang batas hasil pemilu secara nasional untuk dapat ikut serta dalam penghitungan jumlah kursi DPR; (c) Memperkecil district magnitude, maksudnya adalah dengan memperkecil jumlah kursi yang diperebutkan oleh partai politik dalam Pemilu di setiap Dapil; dan (d) Melakukan perubahan metode pengkonversian suara menjadi kursi dari metode kuota Hare menjadi metode kuota Droop, karena dengan penggunaan metode kuota Droop maka jumlah partai yang akan mendapat kursi akan berkurang.

Untuk cara pertama dan kedua sebenarnya telah diadopsi dalam UU Pemilu dalam rangka untuk mengurangi jumlah partai politik yang dapat turut serta dalam pemilu. Namun sayangnya, kedua cara tersebut belum mampu menekan jumlah partai politik secara signifikan. Untuk itu diperlukan electoral engineering yang lain melalui peralihan metode konversi suara dari metode Hare menuju metode Droop dengan disinergikan dengan pengecilan district magnitude di setiap daerah pemilihan. Cara ini merupakan legal engineering yang paling relevan untuk menyederhanakan jumlah partai mengurangi substansi demokrasi yang tetap ingin dibangun di negara ini.

Dalam melihat desain pemilu di Indonesia, haruslah disadari bahwa nantinya output yang dihasilkan dari pemilu harus dapat mengarah pada suatu pemerintahan yang efektif dalam menjalankan program-program kerjanya. Efektif atau tidaknya kinerja pemerintahan di tangan eksekutif tidak bisa dilepaskan dari mekanisme check and balances yang diemban oleh DPR sebagai lembaga legislatif. Namun, terkadang mekanisme saling kontrol saling imbang yang diemban oleh DPR tidak bisa berjalan dengan efektif dikarenakan kepentingan-kepentingan politik yang dimainkan oleh para kader partai politik di lembaga perwakilan rakyat. Permainan kepentingan politik yang semakin menjadi komoditi para politisi di tengah berkembangnya sistem multipartai di Indonesia, sehingga bisa ditarik suatu hipotesis bahwa sistem multipartai sebenarnya tidak sesuai dengan sistem pemerintahan Indonesia yang bernuansa presidensial.

Diperlukan suatu pemikiran untuk merestrukturisasi sistem multipartai dengan mereduksi jumlah partai politik tanpa mengurangi substansi demokrasi yang tengah dibangun di Indonesia. Sejalan dengan hal tersebut, langkah yang dirasa cukup efektif untuk mengurangi jumlah partai politik adalah dengan mengubah metode konversi penghitungan suara ke kursi dari metode kuota Hare (yang digunakan di Indonesia sekarang) menjadi metode kuota Droop. Seiring dengan perubahan metode penghitungan tersebut juga harus dilakukan suatu legal policy untuk memecah daerah pemilihan dalam rangka untuk memperkecil district magnitude. Yang dimaksudkan di sini adalah memisahkan daerah pemilihan yang mempunyai jatah kursi besar, sehingga secara kausal kursi-kursi yang terdapat daerah pemilihan tersebut akan berkurang. Kenapa memisahkan Dapil dan memperkecil jumlah kursi ini disebut sebagai suatu pilihan kebijakan (legal policy), karena sejauh ini seperti yang termaktub dalam UU Pemilu Legislatif untuk tahun 2004, 2009, maupun 2014 pemegang palu kebijakan penentuan daerah pemilihan dan pembagian jumlah kursi berada di tangan DPR.

Untuk melihat keefektifan penggunaan metode kuota Droop maka dapat dilihat dari penerapan hasil perhitungan menggunakan metode kuota Hare dan Droop. Data yang 
digunakan dalam penerapan kuota Hare dan Droop adalah hasil perolehan suara pemilu legislatif DPR RI Tahun 2009 di daerah pemilihan Yogyakarta I yang memiliki jumlah suara sah sebesar 1.752.775 dengan memperebutkan 8 kursi DPR RI. ${ }^{25}$ Berdasarkan UU Nomor 10 Tahun 2008 disebutkan bahwa yang diikutkan dalam perhitungan perolehan kursi hanya partai yang suara sah nasionalnya mencapai sekurangkurangnya $2,5 \%$ dari suara sah nasional, ${ }^{26}$ sehingga suara yang diperhitungkan jumlahnya hanya sebatas yang memenuhi ketentuan tersebut adalah 1.525.030.

Untuk mengetahui efektivitas dari kedua metode tersebut diperlukan data-data pendukung lainnya, seperti: a) Bilangan Pembagi Pemilih:

$\mathrm{BPP}=\frac{\text { suara sah }}{\text { jumlah kursi }}=\frac{1525030}{8}=190628,75 \approx 190629$

b) Koefisien kuota Hare:

Hare Quota $(\mathrm{HQ})=\frac{\text { suara sah }}{\text { jumlah kursi }}=\frac{1525030}{8}=190628,75$

C) Koefisien kuota Droop:

Droop Quota $(\mathrm{DQ})=\frac{\text { suara sah }}{\text { jumlah kursi }+1}=\frac{1525030}{8+1}=\frac{1525030}{9}=169447,778$

Setelah mengetahui koefisien kuota Hare dan Droop, koefisien tersebut digunakan untuk membagi suara sah yang diperoleh partai untuk mengkonversi jumlah suara menjadi jumlah kursi.

Tabel 1. Perolehan Kursi Daerah Pemilihan Yogyakarta I 2009 (Metode Kuota Hare)

\begin{tabular}{|c|l|r|r|r|c|c|}
\hline $\begin{array}{c}\text { No. } \\
\text { Urut }\end{array}$ & \multicolumn{1}{|c|}{ Nama Partai } & \multicolumn{1}{|c|}{$\begin{array}{c}\text { Kuara } \\
\text { Hare }\end{array}$} & $\begin{array}{c}\text { Kursi } \\
\text { Penuh }\end{array}$ & $\begin{array}{c}\text { Kursi } \\
\text { Sisa }\end{array}$ & $\begin{array}{c}\text { Total } \\
\text { Kursi }\end{array}$ \\
\hline 1 & Partai Hati Nurani Rakyat & 41.321 & 0,216761637 & 0 & 0 & 0 \\
\hline 5 & Partai Gerakan Indonesia Raya & 78.254 & 0,410504711 & 0 & 0 & 0 \\
\hline 8 & Partai Keadilan Sejahtera & 159.132 & 0,834774398 & 0 & 1 & 1 \\
\hline 9 & Partai Amanat Nasional & 243.416 & 1,276911274 & 1 & 0 & 1 \\
\hline 13 & Partai Kebangkitan Bangsa & 80.285 & 0,421158928 & 0 & 1 & 1 \\
\hline 23 & Partai Golongan Karya & 258.800 & 1,357612637 & 1 & 0 & 1 \\
\hline 24 & Partai Persatuan Pembangunan & 61.344 & 0,32179826 & 0 & 0 & 0 \\
\hline 28 & Partai Demokrasi Indonesia Perjuangan & 274.679 & 1,440910671 & 1 & 1 & 2 \\
\hline 31 & Partai Demokrat & 327.799 & 1,719567484 & 1 & 1 & 2 \\
\hline Total & & $\mathbf{1 . 5 2 5 . 0 3 0}$ & $\mathbf{8}$ & $\mathbf{4}$ & $\mathbf{4}$ & $\mathbf{8}$ \\
\hline
\end{tabular}

Sumber: Hasil Olahan Penulis.

25 Media Center Komisi Pemilihan Umum, "Hasil Perolehan Suara Partai Politik di D.I. Yogyakarta", http:// mediacenter.kpu.go.id/images/mediacenter/hasil_pileg_2009/dpr/DI_yogyakarta.pdf (diakses 30 Maret 2014).

26 Lihat Pasal 203 ayat (1) Undang-Undang Nomor 10 Tahun 2008 tentang Pemilihan Umum Anggota Dewan Perwakilan Rakyat, Dewan Perwakilan Daerah, dan Dewan Perwakilan Rakyat Daerah (Lembaran Negara Tahun 2008 Nomor 51, Tambahan Lembaran Negara Nomor 4836), "Partai Politik Peserta Pemilu yang tidak memenuhi ambang batas perolehan suara sebagaimana dimaksud dalam Pasal 202 ayat (1), tidak disertakan pada penghitungan perolehan kursi DPR di masing-masing daerah pemilihan." 
Tabel 2. Perolehan Kursi Daerah Pemilihan Yogyakarta I 2009 (Metode Kuota Droop)

\begin{tabular}{|c|c|c|c|c|c|c|}
\hline $\begin{array}{l}\text { No. } \\
\text { Urut }\end{array}$ & Nama Partai & Suara & Kuota Hare & $\begin{array}{l}\text { Kursi } \\
\text { Penuh }\end{array}$ & $\begin{array}{l}\text { Kursi } \\
\text { Sisa }\end{array}$ & $\begin{array}{l}\text { Total } \\
\text { Kursi }\end{array}$ \\
\hline 1 & Partai Hati Nurani Rakyat & 41.321 & 0,243856842 & 0 & & 0 \\
\hline 5 & Partai Gerakan Indonesia Raya & 78.254 & 0,4618178 & 0 & & 0 \\
\hline 8 & Partai Keadilan Sejahtera & 159.132 & 0,939121198 & 0 & + & 1 \\
\hline 9 & Partai Amanat Nasional & 243.416 & 1,436525183 & 1 & 0 & 1 \\
\hline 13 & Partai Kebangkitan Bangsa & 80.285 & 0,473803794 & 0 & 0 & 0 \\
\hline 23 & Partai Golongan Karya & 258.800 & 1,527314217 & 1 & 1 & 2 \\
\hline 24 & Partai Persatuan Pembangunan & 61.344 & 0,362023042 & 0 & 0 & 0 \\
\hline 28 & $\begin{array}{l}\text { Partai Demokrasi Indonesia Perjuan- } \\
\text { gan }\end{array}$ & 274.679 & 1,621024504 & & 1 & 2 \\
\hline 31 & Partai Demokrat & 327.799 & 1,934513419 & 1 & 1 & 2 \\
\hline \multicolumn{2}{|l|}{ Total } & 1.525 .030 & 9 & 4 & 4 & 8 \\
\hline
\end{tabular}

Sumber: Hasil Olahan Penulis

Dari tabel di atas, terlihat bahwa dengan menggunakan metode kuota Droop maka akan mengeliminir jumlah partai politik untuk memperoleh kursi di DPR. Dalam tabel di atas yang tersingkir dari jatah kursinya adalah Partai Kebangkitan Bangsa (PKB), yang semula ${ }^{27}$ dengan metode kuota Hare memperoleh 1 buah kursi maka setelah digunakan metode kuota Droop, PKB kehilangan kursi dikarenakan tidak memenuhi kuota kursi penuh maupun kuota sisa kursi.
Metode kuota Droop merupakan metode yang paling banyak dan paling jamak digunakan oleh negara-negara di dunia baik negara penganut Single Transferable Vote (STV) maupun List Proportional Representation (List-PR). Indonesia sebagai negara yang juga menerapkan List-PR adalah salah satu negara yang tidak menerapkan metode kuota Droop. Tidak ada yang salah sebenarnya dengan tidak diterapkannya metode kuota Droop, karena cara tersebut merupakan legal policy, akan tetapi 
dalam konteks merancang suatu konstruksi demokrasi yang bukan semata euforia, maka perlu ditelaah suatu perbaikan sistem pemilu, disinilah metode kuota Droop bisa masuk sebagai salah satu bentuk perbaikan sistem pemilu.

Dengan penggunaan metode ini maka akan mereduksi secara alami jumlah partai politik yang duduk di parlemen. Dengan metode Droop ini keinginan untuk menyederhanakan sistem multipartai dapat terwujud. Sejalan dengan digunakannya metode kuota Droop dapat berdampak lebih signifikan dalam menyederhanakan partai politik ketika jumlah kursi yang diperebutkan (district magnitude) dapat diperkecil dengan cara melakukan pemisahan daerah pemilihan yang mempunyai jatah kursi yang besar. Nantinya diharapkan dengan semakin sedikitnya partai politik yang duduk di lembaga perwakilan rakyat maka kondisi pemerintahan presidensial akan berjalan semakin efektif, sehingga semangat purifikasi sistem presidensial dapat tercapai sesuai amanat UUD NRI Tahun 1945.

\section{E. Penutup}

\section{Kesimpulan}

Dari keterangan, uraian dan pembahasan di atas dapat disimpulkan sebagai berikut: Pertama, implikasi perpaduan antara sistem presidensial dan sistem kepartaian multipartai di Indonesia menghasilkan pemerintahan yang dapat dikatakan belum efektif dikarenakan kooptasi oleh kepentingan politik yang dibawa oleh partai politik di DPR. Kemunculan banyak partai politik adalah suatu kausalitas berlakunya sistem multipartai tanpa adanya suatu mekanisme kontrol untuk membatasi jumlah partai politik secara kualitatif. Sistem pemerintahan Indonesia yang bersifat presidensial tidak kompatibel dengan sistem multipartai. Tidak pula bisa diartikan tidak cocok secara keseluruhan, namun sistem multipartainya nantinya akan mereduksi kekuasaan presiden dalam mengeksekusi program-program kerjanya, sehingga diperlukan suatu desain kepartaian di Indonesia yang lebih ramah terhadap sistem presidensial di Indonesia.

Kedua, Indonesia menggunakan sistem List PR with Open List System, yang mana di dalam sistem List $P R$, transfer suara ke kursi bisa dilakukan melalui suara sisa terbesar (largest remainder) atau disebut dengan kuota. Largest remainder digunakan untuk melakukan penghitungan suara. Langkah-langkahnya adalah menentukan kuota suara dan besarnya kursi yang diperoleh masing-masing partai berdasarkan jumlah suara yang diperoleh. Sementara sisa suara yang belum terbagi akan diberikan kepada parpol yang mempunyai jumlah sisa suara terbesar.

Ketiga, desain kepartaian yang harus dikembangkan adalah sistem multipartai sederhana. Legal engineering untuk mengarahkan desain kepartaian Indonesia adalah dengan melakukan transformasi metode konversi suara menjadi kursi yang semula menggunakan metode kuota Hare digantikan dengan metode kuota Droop diiringi dengan legal policy untuk memisahkan daerah pemilihan yang memiliki jumlah kursi yang besar dalam rangka untuk memperkecil district magnitude atau jumlah kursi yang diperebutkan oleh partai politik dalam Pemilu. Diharapkan dengan tercapainya desain kepartaian dan desain Pemilu tersebut dalam semakin mengokohkan sistem presidensial di Indonesia dan semakin menciptakan suatu pemerintahan yang efektif. 


\section{Saran}

Sebagai penutup, berikut adalah beberapa rekomendasi yang bersifat konstruktif, yaitu: Pertama, untuk mencapai sistem pemerintahan yang efektif diperlukan suatu desain kepartaian dan desain pemilu yang sejalan dengan ruh sistem presidensial di Indonesia. Desain kepartaian yang dirasa cukup efektif adalah mengarahkan sistem kepartaian di Indonesia menuju sistem multipartai sederhana. Kedua, menciptakan suatu desain pemilu yang dapat menjadi mekanisme kontrol sistem multipartai dan dapat mereduksi jumlah partai politik, yaitu selain dengan mengaplikasikan threshold yang ada, juga dengan melakukan legal engineering berupa perubahan metode pengonversian jumlah suara menjadi jumlah kursi dari metode kuota Hare dirubah menjadi metode kuota Droop diiringi dengan legal policy untuk memisahkan daerah pemilihan dengan jumlah kursi yang besar dalam rangka memperkecil district magnitude dalam Pemilu. Ketiga, dengan dilaksanakan langkah-langkah di atas diharapkan dapat terwujud suatu sistem bernegara yang kondusif yang pada muaranya bertujuan untuk menciptakan suatu effective governance.

\section{DAFTAR PUSTAKA}

\section{Buku}

Amal, Ichlasul, Teori-Teori Mutakhir Partai Politik (Yogyakarta: Gadjah Mada University Press, 1996).

Budiardjo, Miriam, Dasar-Dasar Ilmu Politik (Jakarta: Gramedia Pustaka Utama, 2003).

Dewan Perwakilan Rakyat RI, Program Legislasi Nasional Tahun 2010-2014 (Jakarta: Badan Legislasi DPR RI, 2010).

Kelompok Kerja Forum Rektor Indonesia, Penyempurnaan Amandemen Undang-Undang Dasar 1945 (Hasil Kerja Kelompok Kerja Forum
Rektor Indonesia 2006-2007) (Yogyakarta: Gadjah Mada University Press, 2007).

Pamungkas, Sigit, Perihal Pemilu (Yogyakarta: Laboratorium Jurusan Ilmu Pemerintahan dan Jurusan Ilmu Pemerintahan Universitas Gadjah Mada, 2009).

Reilly, Ben, dan Andrew Reynolds, Electoral Systems and Conflict in Divided Societies (Washington DC: National Academy Press, 1999).

Sartori, Giovanni, Comparative Constitutional Engineering: An Inquiry into Structure, Incentives, and Outcomes (London: Macmillan Press Ltd., 1997).

Seligman, Lester G., dan Cary R. Covington, The Coalitional Presidency (Chicago: Dorsey Press, 1989).

Surbakti, Ramlan, Didik Supriyanto, dan Topo Santoso, Perekayasaan Sistem Pemilu untuk Pembangunan Tata Politik Demokratis (Jakarta: Partnership for Governance Reform Indonesia, 2008).

Makalah / Artikel / Prosiding / Hasil Penelitian

Dwipayana, Mengenal Beberapa Sistem Pemilu (Yogyakarta: Fakultas Ilmu Sosial dan IImu Politik Universitas Gadjah Mada, Yogyakarta).

Engers, Tom M. van, "Legal Engineering: A Structural Approach to Improving Legal Quality" (Paper on Applications and Innovations in Intelligent Systems XIII, Proceedings of AI-2005).

Indrayana, Denny, "Sistem Pemilu Presiden/Wakil Presiden 2009", (Bahan Kuliah Video Conference diselenggarakan oleh Fakultas Hukum Universitas Gadjah Mada dengan Mahkamah Konstitusi RI, Yogyakarta, 19 Februari 2009).

Husein, Harun, "Berhitung Kursi Secara Fair", Republika, 12 Juli 2011.

Sparingga, Daniel, "Penyederhanaan Partai, Agenda Reformasi", Suara Karya, 14 Juli 2007.

\section{Internet}

Ahyar, "Drama Sandera Kebijakan Presiden SBY Menaikkan Harga BBM Bersubsidi untuk Rakyat Miskin", http://www.ronamasa.com/2013/06/ drama-sandera-kebijakan-presiden-sby.html (diakses 30 Maret 2014).

Hukum Online, "DPR Tetapkan 66 RUU Prolegnas 2014", http://www.hukumonline.com/berita/ baca/It52b063fdb092e/dpr-tetapkan-66-ruuprolegnas-2014 (diakses 29 Maret 2014). 
Mahkamah Konstitusi RI, "Rekapitulasi Perkara Pengujian Undang-Undang", http:// www.mahkamahkonstitusi.go.id/index. php?page=web.RekapPUU (diakses 30 Maret 2014).

Media Center Komisi Pemilihan Umum, "Daftar Calon Terpilih Anggota Dewan Perwakilan Rakyat Republik Indonesia Hasil Pemilu Tahun 2009", http://mediacenter.kpu.go.id/images/ mediacenter/DIDI/DAFTAR_ANGGOTA_ DPR_2009.pdf (diakses 30 Maret 2014).

Media Center Komisi Pemilihan Umum, "Hasil Perolehan Suara Partai Politik di D.I. Yogyakarta", http://mediacenter.kpu.go.id/ images/mediacenter/hasil_pileg_2009/dpr/DI_ yogyakarta.pdf (diakses 30 Maret 2014).

\section{Peraturan}

Undang-Undang Dasar Negara Republik Indonesia Tahun 1945.

Undang-Undang Nomor 10 Tahun 2008 tentang Pemilihan Umum Anggota Dewan Perwakilan Rakyat, Dewan Perwakilan Daerah, dan Dewan Perwakilan Rakyat Daerah (Lembaran Negara Tahun 2008 Nomor 51, Tambahan Lembaran Negara Nomor 4836).
Undang-Undang Nomor 8 Tahun 2012 tentang Pemilihan Umum Dewan Perwakilan Rakyat, Dewan Perwakilan Daerah dan Dewan Perwakilan Rakyat Daerah (Lembaran Negara Republik Indonesia Tahun 2012 Nomor 117, Tambahan Lembaran Negara Republik Indonesia Nomor 5316).

Putusan Mahkamah Konstitusi Nomor 22-24/PUU$\mathrm{VI} / 2008$ perihal Pengujian Undang-Undang Nomor 10 Tahun 2008 tentang Pemilihan Umum Anggota Dewan Perwakilan Rakyat, Dewan Perwakilan Daerah, dan Dewan Perwakilan Rakyat Daerah terhadap Undang-Undang Dasar Negara Republik Indonesia Tahun 1945.

\section{Putusan Pengadilan}

Putusan Mahkamah Konstitusi Nomor 3/PUUVII/2009 perihal Pengujian Undang-Undang Nomor 10 Tahun 2008 tentang Pemilihan Umum Anggota Dewan Perwakilan Rakyat, Dewan Perwakilan Daerah, dan Dewan Perwakilan Rakyat Daerah terhadap Undang-Undang Dasar Negara Republik Indonesia Tahun 1945. 